\title{
Expression and Localization of a Rhizobium-Derived Cambialistic Superoxide Dismutase in Pea (Pisum sativum) Nodules Subjected to Oxidative Stress
}

\author{
Aaron C. Asensio, ${ }^{1}$ Daniel Marino, ${ }^{2}$ Euan K. James, ${ }^{3}$ Idoia Ariz,, Cesar Arrese-Igor, ${ }^{2}$ \\ Pedro M. Aparicio-Tejo, ${ }^{1}$ Raúl Arredondo-Peter, ${ }^{4}$ and Jose F. Moran ${ }^{1}$ \\ ${ }^{1}$ Institute of Agro-Biotechnology, IdAB-CSIC-UPNa-GN, Public University of Navarre, Spain; ${ }^{2}$ Department of Environmental \\ Sciences, Public University of Navarre, Spain; ${ }^{3}$ Scottish Crop Research Institute, Invergowrie, Dundee DD2 5DA, U.K.; \\ ${ }^{4}$ Laboratorio de Biofísica y Biología Molecular, Facultad de Ciencias, Universidad Autónoma del Estado de Morelos, \\ Cuernavaca, Morelos, México
}

Submitted 31 October 2010. Accepted 23 June 2011.

Two phylogenetically unrelated superoxide dismutase (SOD) families, i.e., CuZnSOD (copper and zinc SOD) and FeMnCamSOD (iron, manganese, or cambialistic SOD), eliminate superoxide radicals in different locations within the plant cell. CuZnSOD are located within the cytosol and plastids, while the second family of SOD, which are considered to be of bacterial origin, are usually located within organelles, such as mitochondria. We have used the reactive oxygen species-producer methylviologen (MV) to study SOD isozymes in the indeterminate nodules on pea (Pisum sativum). MV caused severe effects on nodule physiology and structure and also resulted in an increase in SOD activity. Purification and N-terminal analysis identified CamSOD from the Rhizobium leguminosarum endosymbiont as one of the most active SOD in response to the oxidative stress. Fractionation of cell extracts and immunogold labeling confirmed that the CamSOD was present in both the bacteroids and the cytosol (including the nuclei, plastids, and mitochondria) of the $\mathrm{N}$-fixing cells, and also within the uninfected cortical and interstitial cells. These findings, together with previous reports of the occurrence of FeSOD in determinate nodules, indicate that FeMnCamSOD have specific functions in legumes, some of which may be related to signaling between plant and bacterial symbionts, but the occurrence of one or more particular isozymes depends upon the nodule type.

Reactive oxygen species (ROS) are unavoidable by-products of aerobic life, being constantly produced during normal metabolic processes, such as respiration, photosynthesis, or biological $\mathrm{N}$ fixation (BNF). ROS production can also be crucial for plant growth, and its signaling role during plant-microbe inter-

Aaron C. Asensio and Daniel Marino contributed equally to this work.

Current address for Daniel Marino: Laboratoire des Interactions PlantesMicroorganismes, UMR CNRS 2594 - INRA 441, Chemin de Borde Rouge BP 52627, F-31326, Castanet-Tolosan Cedex, France.

Corresponding author: Jose F. Moran: Telephone: +34 948168018; Fax: +34 948 168930; E-mail: jose.moran@unavarra.es

* The $e$-Xtra logo stands for "electronic extra" and indicates that four supplementary figures are published online. actions has been recently demonstrated during both pathogenesis and symbiosis (Marino et al. 2009; Torres 2010). However, when produced at high levels, as under biotic or abiotic stress, natural or induced senescence, or after exposure to xenobiotics, they can be lethal to cell integrity, owing to their capacity to damage proteins, lipids, and DNA (Apel and Hirt 2004).

Superoxide dismutases (SOD) act as a first line of defense against the superoxide radical $\left(\mathrm{O}_{2}^{-}\right)$. Two phylogenetically unrelated superoxide dismutase families, i.e., CuZnSOD (copper and zinc SOD) and the group of FeMnCamSOD (iron, manganese, and cambialistic SOD), can be found in different locations within legume cells and rhizobial bacteroids (Bannister et al. 1987). Cytosolic and plastidial CuZnSOD isozymes are common to all plant cells and are found in determinate and indeterminate nodules (Moran et al. 2003; Rubio et al. 2004, 2009). As well as being present in the cytoplasm of cells from various nodule types (Rubio et al. 2004, 2009), cytosolic CuZnSOD are also localized on chromatin in the nuclei of infected and uninfected cells in root nodules, stem nodules, and leaves of the semiaquatic tropical legume Sesbania rostrata (Rubio et al. 2009). Plastidial CuZnSOD isoenzymes are less abundant in nodules, as they are strongly linked to photosynthesis, but photosynthetic stem nodules on Sesbania rostrata are an exception (Rubio et al. 2009).

The second SOD family includes MnSOD, FeSOD, and CamSOD, which all share high protein sequence and structure similarity (Alscher et al. 2002; Bannister et al. 1987). MnSOD are typical bacterial and mitochondrial SOD and, in nodules, are localized on bacteroids and on mitochondria within both infected and uninfected cells (Rubio et al. 2004, 2009). FeSOD have long been known to be associated with chloroplasts (Alscher et al. 2002; Bannister et al. 1987; Rubio et al. 2009), and they are also found in phototrophic diazotrophic organisms, such as the Anabaena sp. that exhibits a FeSOD specifically within heterocysts ( $\mathrm{Li}$ et al. 2002). In legume nodules, in addition to an FeSOD being localized within plastids (Rubio et al. 2009), determinate nodule-forming legumes such as cowpea and soybean also have a distinct FeSOD in the cytosol, whose function has been suggested to be associated with nodule effectiveness (Moran et al. 2003). However, as yet, no FeSOD has been detected in the cytosol of classically indeterminate nodules, such as those on temperate crop legumes like pea (Moran et al. 2003), although it has been recently found to 
be associated with nuclear chromatin in nodules on Sesbania rostrata (Rubio et al. 2009). Indeed, the role of nonplastidial Fe-containing SOD (and their essentiality) in various nodule types is not yet fully understood, especially as there is the intriguing possibility that in some nodule types (e.g., temperate indeterminate ones) the roles of FeSOD can be wholly or partially undertaken by a related group of bacterially derived SOD, the so-called CamSOD.

CamSOD, which have so far only been found in bacteria and diatoms, may have either Fe or $\mathrm{Mn}$ as a ligand, depending on the availability of these metals, and show differences in activity, $\mathrm{pH}$, and thermal stability depending on the $\mathrm{Mn}$ or Fe content of the active center (Ken et al. 2005; Santos et al. 1999). A CamSOD has been shown to be required for effective nodule function in the Medicago sativa-Sinorhizobium meliloti symbiosis, but its role was considered exclusively to operate within the bacteroids (Santos et al. 1999, 2000) and little else is known about it in terms of its activity or location within nodules. In this study, we have applied methylviologen (MV), a compound sometimes referred to by the commercial name Paraquat, which exacerbates $\mathrm{O}_{2}^{-}$production in the nutrient solution of nodulated pea plants to provoke a mild oxidative stress and, thereby, induce the antioxidant systems that allowed for the better study of the SOD protein family in pea nodules. We report the induction of elevated bacterial CamSOD activity, which was found to be localized not only within the Rhizobium microsymbiont but also within different plant cell compartments of both infected and uninfected cells.

\section{RESULTS}

\section{Effect of MV-mediated oxidative stress on nitrogen fixation and nodule functioning.}

We applied MV in the nutrient solution of plants growing in hydroponic culture. This resulted in a more homogeneous application compared with using a short spot foliar application, and thus imposed a more progressive oxidative stress on the nodules while avoiding a strong effect on the shoot that would have caused rapid plant death. As well as affecting plant growth and photosynthesis, the MV treatment also markedly decreased nitrogen fixation almost to the point of cessation (Table 1). Nodule plant-fraction protein contents were also significantly reduced $(-35 \%)$ by MV stress, but bacteroid protein contents were relatively unaffected $(-11 \%)$. Among the proteins and enzymes analyzed, the most striking effect of MV was on leghemoglobin (Lb), the main cytosolic protein within

Table 1. Effects of methylviologen (MV) on pea $^{\mathrm{x}}$

\begin{tabular}{|c|c|c|}
\hline Parameter $^{\mathrm{y}}$ & Control $^{\mathrm{z}}$ & $\mathbf{M V}^{\mathbf{z}}$ \\
\hline Plant dry weight $\left(\right.$ g plant $\left.^{-1}\right)$ & $0.62 \pm 0.08 \mathrm{a}$ & $0.51 \pm 0.04 b$ \\
\hline Photosynthesis $\left(\mu \mathrm{mol} \mathrm{CO} \mathrm{CO}_{2} \mathrm{~m}^{-2} \mathrm{~s}^{-1}\right)^{*}$ & $4.47 \pm 0.84 \mathrm{a}$ & $2.60 \pm 0.37 \mathrm{~b}$ \\
\hline Chlorophylls (SPAD units)* & $47.10 \pm 2.2 \mathrm{a}$ & $37.1 \pm 1.6 \mathrm{~b}$ \\
\hline 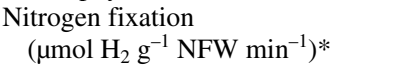 & $0.056 \pm 0.007 \mathrm{a}$ & $0.002 \pm 0.001 \mathrm{~b}$ \\
\hline $\begin{array}{l}\text { Nodule plant fraction protein } \\
\left(\mathrm{mg} \mathrm{g}^{-1} \mathrm{NFW}\right)^{*}\end{array}$ & $10.21 \pm 0.71 \mathrm{a}$ & $6.63 \pm 0.71 b$ \\
\hline $\begin{array}{l}\text { Nodule bacteroid protein } \\
\left(\mathrm{mg} \mathrm{g}^{-1} \mathrm{NFW}\right)\end{array}$ & $5.72 \pm 0.40 \mathrm{a}$ & $5.11 \pm 0.36 \mathrm{a}$ \\
\hline Leghemoglobin (mg g ${ }^{-1}$ NFW) & $0.81 \pm 0.20 \mathrm{a}$ & $0.14 \pm 0.11 \mathrm{~b}$ \\
\hline ASC/DHA & $0.66 \pm 0.01 \mathrm{a}$ & $0.17 \pm 0.02 b$ \\
\hline GSH/GSSG & $24.20 \pm 9.0 \mathrm{a}$ & $5.5 \pm 0.9 \mathrm{~b}$ \\
\hline
\end{tabular}

${ }^{\mathrm{x}}$ Effects of a 4-day root application of $10 \mu \mathrm{M} \mathrm{MV}$ on various physiological and biochemical parameters related to growth, photosynthesis, nitrogen fixation and the antioxidant capacity of nodulated pea plants.

${ }^{y}$ Asterisks (*) indicate data taken from Marino et al. 2006. NFW denotes nodule fresh weight.

${ }^{\mathrm{z}}$ Mean \pm standard error $(n=6)$. Numbers followed by a different letter within a row are significantly different at $P \leq 0.05$. the nodule (approximately $1 \mathrm{mM}$ ), which suffered an $82 \%$ reduction in concentration (Table 1). The MV treatment also evidently caused an alteration in the nodule cell redox state, as ascorbate (ASC) and reduced glutathione (GSH), which are the main soluble antioxidants within nodules, were highly oxidized, resulting in a striking $75 \%$ decline in both ASC/DHA (dehydroascorbate) and GSH/GSSG (oxidized glutahione) ratios (Table 1).

The MV application adversely affected nodule structure, as can be seen by light microscopy and transmission electron microscopy (TEM) (Fig. 1). Nodules from untreated control plants had infected cells that were typically turgid with a round central vacuole (Fig. 1A). These were packed with bacteroids surrounded by a symbiosome membrane so that there was a very narrow space between bacteroids and the symbiosome membrane (Fig. 1B). Both the bacteroid and host cell cytoplasm was electron dense, with the host cytoplasm containing numerous intact organelles (Fig. 1B). However, at a relatively low concentration of MV $(1 \mu \mathrm{M})$, degradation of infected cells was evident, with the formation of large vacuoles (Fig. 1C), and at the ultrastructural level, it could be seen that these were formed largely through the expansion of the symbiosome spaces so that they coalesced into larger vacuoles (Fig. 1D). The bacteroids were distorted in shape compared with controls and were less electron-dense, suggesting that they were losing cytoplasmic integrity (Fig. 1D). At a higher concentration of MV $(10 \mu \mathrm{M})$, both infected and uninfected cells appeared to be plasmolyzed, i.e., they were distorted in shape and without a central vacuole, with the cell contents pulled away from the cell wall (Fig. 1E). The bacteroids, which were now very distorted in shape, were no longer surrounded by intact symbiosomes and the host cytoplasm had been reduced to fragments (Fig. 1F). Interestingly, the bacteroids in nodules subjected to both MV treatments could still be immunogold-labeled with an antibody against the nifH protein (Fe-protein) of the nitrogenase enzyme complex (Supplementary Fig. S1).

\section{Effect of MV-mediated oxidative stress, aging, and excess Fe on SOD isozymes in pea nodules.}

Nodules and leaves from pea plants showed different patterns of SOD activity (Fig. 2). Four isozymes were found in nodule tissues, while five different bands could be observed in leaves (Fig. 2A). Based on their mobility in native gels and their differential inhibition by $\mathrm{KCN}$ (Fig. 2B) or $\mathrm{H}_{2} \mathrm{O}_{2}$ (Fig. 2C), a MnSOD and cytosolic or plastidial CuZnSOD could be easily identified (Fig. 2B and C). A fourth band, with a mobility intermediate between MnSOD and cytosolic CuZnSOD showed strong activity (Fig. 2A); this SOD exhibited a mobility typical of an FeSOD isozyme, but it resisted the cyanide (Fig. 2B) and hydrogen peroxide (Fig. 2C) treatments that characterize MnSOD and CamSOD (Santos et al. 1999). Although this putative CamSOD was not present within the leaf extracts, two FeSOD could be observed that were not present in nodules (Fig. 2A).

The SOD activities of nodules were affected by the MV-mediated oxidative stress, with the putative CamSOD showing one of the greatest increases $(+84 \%)$ among the responses of all the SOD isozymes to MV application (Fig. 2A). The gels in Figure 2 are representative examples of four replicate experiments. In each experiment, the total activity of the CamSOD was the highest among all the SOD isozymes examined. Large increases after MV treatment were also observed in the nodule activities of cytosolic CuZnSOD (+157\%) and (to a lesser extent) of MnSOD (Fig. 2A). In contrast, the plastidic CuZnSOD activity, although it increased after application of MV, still represented a low proportion of the total SOD activity in nodules (Fig. 2A). In leaves, the activity of the cytCuZnSOD isozyme 
was significantly induced after application of MV, while those of plCuZnSOD and FeSOD were virtually unchanged (Fig. 2A).

In order to study the effects of age on the SOD activities of pea nodules, analyses were performed on nodule populations from plants up to 10 weeks old (Fig. 3). Although the putative CamSOD again showed the highest activity, no important differences in activity of any SOD isozymes were found associated with increasing nodule age. The exception was in extracts of nodules from plants at 10 weeks, which showed a slight de- crease in intensity of the putative CamSOD band and an increase in intensities of the two CuZnSOD bands compared with extracts from younger nodules (Fig. 3). The response of nodule SOD to Fe excess was also determined in an attempt to elucidate the regulating role of $\mathrm{Fe}$ in CamSOD activity; a treatment with $\mathrm{Fe}$ (III)-EDTA increased the activity of the putative CamSOD, while the plant mitochondrial MnSOD was increased to a lower extent (Fig. 4). On the contrary, both CuZnSOD isozymes were reduced in activity.
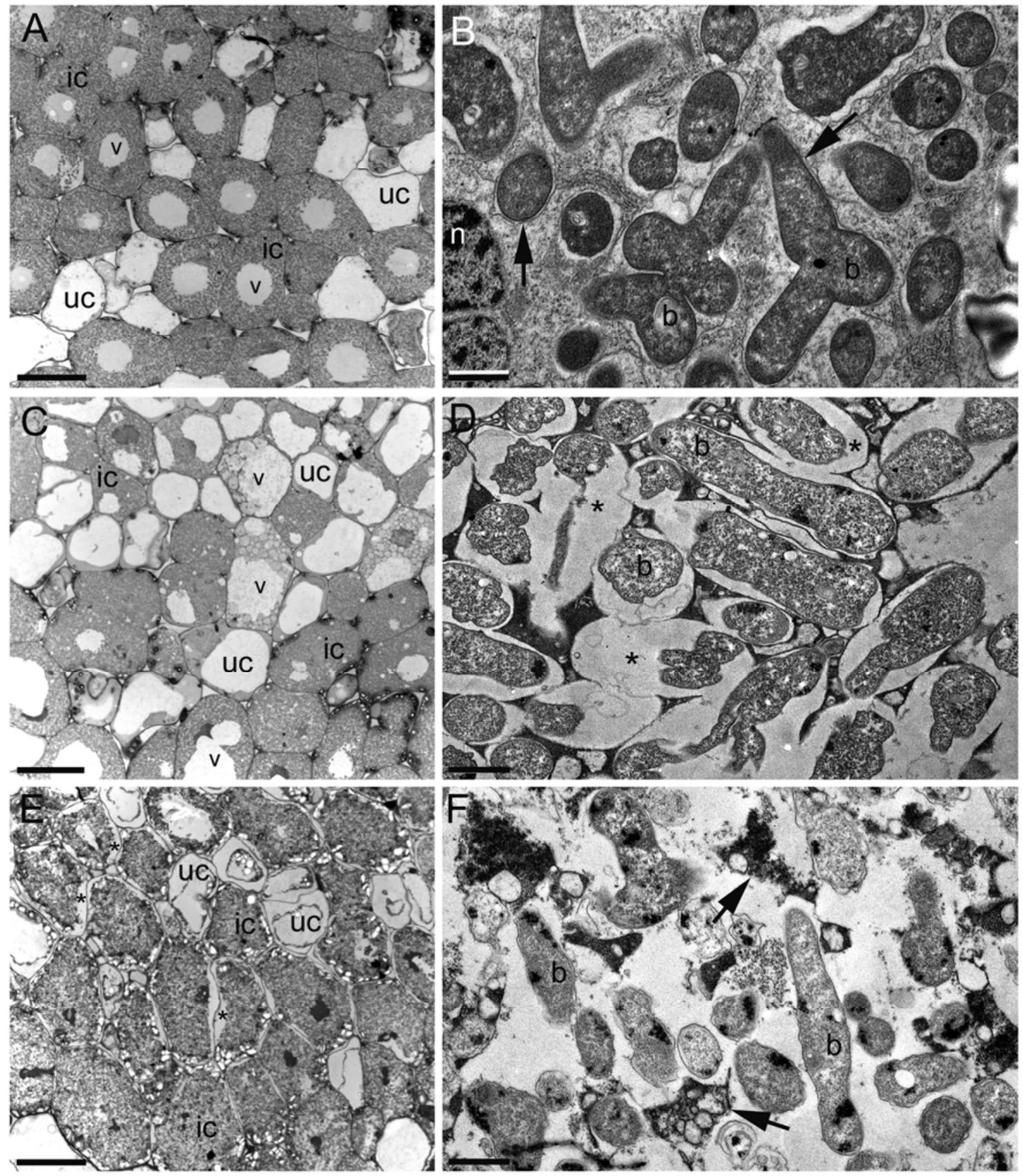

Fig. 1. A, C, and E, Light microscopy and $\mathbf{B}, \mathbf{D}$, and $\mathbf{F}$, transmission electron microscopy of pea nodules from untreated control plants (A, B), plants treated with $1 \mu \mathrm{M}$ methylviologen (MV) (C, D), and plants treated with $10 \mu \mathrm{M}$ MV (E, F). A, Untreated nodules had infected cells (ic) that were healthy in appearance with a regular shape and each had a single central vacuole (*). B, They contained electron dense bacteroids of Rhizobium leguminosarum bv. viciae, many of them typically pleiomorphic (b), which were located singly within each symbiosome. Note that there was only a narrow gap between the bacteroids and the symbiosome inner membranes (arrows). $\mathrm{n}$ = nucleus. C, Infected cells in nodules treated with $1 \mu \mathrm{M}$ MV were less regular in shape and less densely stained than controls and the vacuoles in many were enlarged (v). Uninfected cells (uc) appeared to be relatively unaffected by the treatment. D, Bacteroids (b) were less electron-dense, many were distorted compared with controls, and the symbiosome spaces (*) were greatly enlarged. E, Infected cells in nodules treated with $10 \mu \mathrm{M}$ MV were even more distorted in shape, suggesting a loss of turgor, and very few of them had vacuoles, but many had spaces $(*)$ between the cytoplasm and the cell wall. Uninfected cells (uc) had similar spaces. F, Bacteroids (b) were still recognizable, but host cell cytoplasm had largely disintegrated with only fragments remaining (arrows). Scale bars $=20 \mu \mathrm{m}(\mathrm{A}, \mathrm{C}, \mathrm{E})$ and $1 \mu \mathrm{m}(\mathrm{B}, \mathrm{D}, \mathrm{F})$. 


\section{Identification of a CamSOD}

from Rhizobium leguminosarum within pea nodule extracts.

The putative CamSOD was purified after anion exchange chromatography, using a MonoQ column, native polyacrylamide gel electrophoresis (PAGE), and sodium dodecyl sulfate (SDS)-PAGE. After transfer to polyvinylidene diflouride (PVDF) membranes and staining, a major band was visualized between 22 and $28 \mathrm{kDa}$ (Fig. 5). This band was further examined by $\mathrm{N}$-terminal sequencing, and the 18 initial residues found for the polypeptide were $\mathrm{NH}_{2}{ }^{+}$-AFELPELPYDYEALA PFM, which corresponded to the $\mathrm{N}$-terminal sequence of the protein encoded by the $\operatorname{sod} A$ gene of $R$. leguminosarum, a
CamSOD (UniProtKB accesion number Q1MJM3-1; Young et al. 2006). The protein has 200 amino acids and a theoretical molecular mass of $22 \mathrm{kDa}$, which matches the size of the band purified for sequencing (Fig. 5). The putative CamSOD from $R$. leguminosarum shares high similarity $(86 \%)$ to the $S$. meliloti CamSOD protein and to a putative CamSOD from Brucella ceit (83\%). This homology, together with the reported mobility of the protein and its tolerance to peroxide (Fig. 2), are strong evidence that this putative CamSOD is, in fact, a true CamSOD. Moreover, an analysis of the metals in one of the purified CamSOD batches demonstrated the presence of $\mathrm{Mn}$ but not of $\mathrm{Fe}$ (not shown).
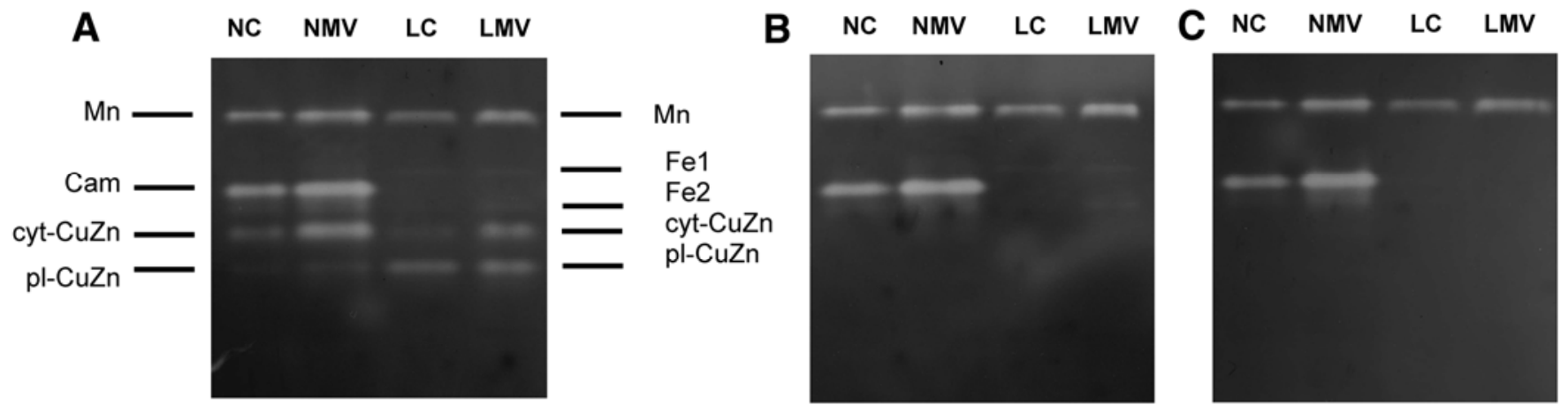

\begin{tabular}{c|cccc}
\hline & NC & NMV & LC & LMV \\
\hline MnSOD & 100 & $130 \pm 11$ & 100 & $125 \pm 9$ \\
CamSOD & 100 & $184 \pm 17$ & - & - \\
FeSOD1 & - & - & 100 & $99 \pm 23$ \\
FeSOD2 & - & - & 100 & $122 \pm 24$ \\
Cyt-CuZnSOD & 100 & $257 \pm 32$ & 100 & $212 \pm 37$ \\
PI-CuZnSOD & 100 & $170 \pm 30$ & 100 & $114 \pm 19$ \\
\hline
\end{tabular}

Fig. 2. Inhibitory studies of superoxide dismutase activity in 4-week-old pea nodules and leaves. Native gels were preincubated either with $\mathbf{A}$, potassium phosphate buffer ( $\mathrm{pH}$ 7.8), B, buffer plus $\mathrm{KCN}$, or $\mathbf{C}$, with buffer plus $\mathrm{H}_{2} \mathrm{O}_{2}$. All lanes were loaded with $60 \mu \mathrm{g}$ of protein. Densitometries of the bands from methylviologen (MV) treatment are expressed as percentages relative to the corresponding control bands (lower panel) Values are means \pm standard error $(n=4) . \mathrm{NC}=$ control nodules, $\mathrm{NMV}=$ methylviologen $(\mathrm{MV})$-treated nodules, $\mathrm{LC}=$ control leaves, and LMV $=\mathrm{MV}$-treated leaves.

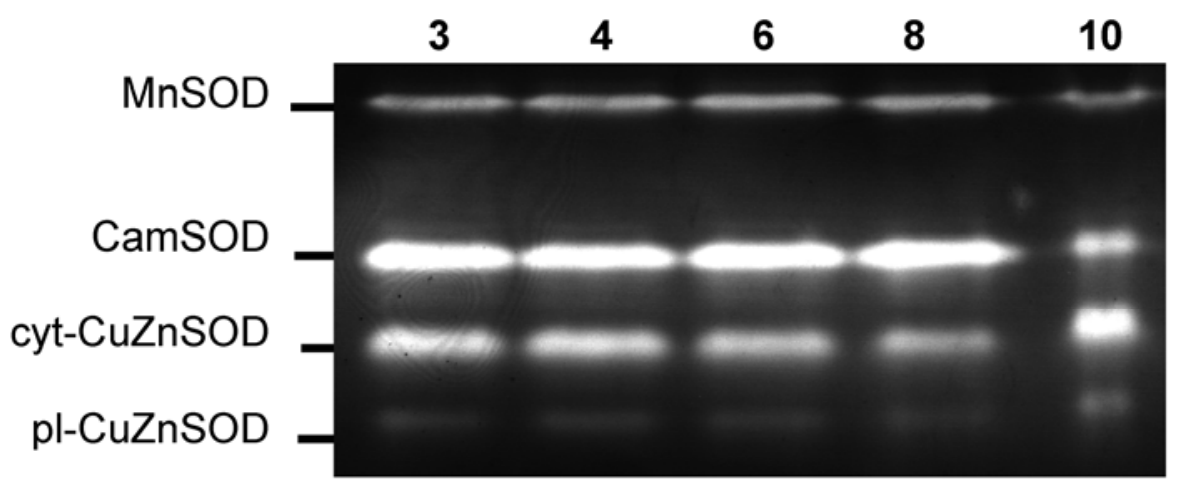

\begin{tabular}{c|ccccc}
\hline & $\mathbf{3}$ & $\mathbf{4}$ & $\mathbf{6}$ & $\mathbf{8}$ & $\mathbf{1 0}$ \\
\hline MnSOD & 100 & 99 & 110 & 112 & 93 \\
CamSOD & 100 & 92 & 96 & 94 & 75 \\
Cyt-CuZnSOD & 100 & 88 & 83 & 78 & 126 \\
PI-CuZnSOD & 100 & 95 & 105 & 114 & 186 \\
\hline
\end{tabular}

Fig. 3. Superoxide dismutase activity in pea nodules of 3-, 4-, 6-, 8-, and 10-week-old Pisum sativum cv. Sugar snap pea plants. All lanes were loaded with $45 \mu \mathrm{g}$ of protein. Densitometry analysis showed no differences between lanes except for nodules on 10-week-old plants. 
An antibody against the CamSOD was raised in rabbits for immunological assays. Based on the sequence of the protein (Fig. 6) and its three-dimensional (3-D) protein model (Supplementary Fig. S2), a peptide was selected in an exposed position of the 3-D structure that would theoretically allow the use of the antibody under nondenaturing conditions. To test the specificity of the antibody, two different immunoblots were conducted (Fig. 7). The first, under denaturing conditions, showed only one band at the molecular weight expected for the CamSOD (Fig. 7A). The second immunoblot was from a native PAGE gel with two sets of pea root and nodule extracts loaded onto it. One set of the root/nodule extracts was subsequently excised from the gel and was transferred to a PVDF membrane to be used for an immunoblot, while the other was stained using an in-gel SOD activity assay; only one band was detected in nodule extracts under native conditions, and this was at the same weight as the CamSOD activity detected by the in-gel SOD activity assay (Fig. 7B). CamSOD protein or activity was not detected in root extracts (Fig. 7B), thus indicating its specificity to nodular tissue.

\section{Subcellular localization of CamSOD.}

We showed above that CamSOD is one of the main responsive SOD in activity assays of nodule extracts exposed to MVmediated oxidative stress (Fig. 2). These extracts were presumed to be free of bacteroids because of the extraction method used to obtain them, but in order to confirm that CamSOD was present within the plant fraction of nodules even though it is encoded by the rhizobial microsymbiont, nodule compartments were fractionated, using a very mild protein extraction followed by differential centrifugations. Immunoblots using the antiCamSOD antibody and an anti-nitrogenase (anti-nifDK) antibody were performed (Fig. 8) on the fractions obtained, and the results indicated that the CamSOD enzyme was present in

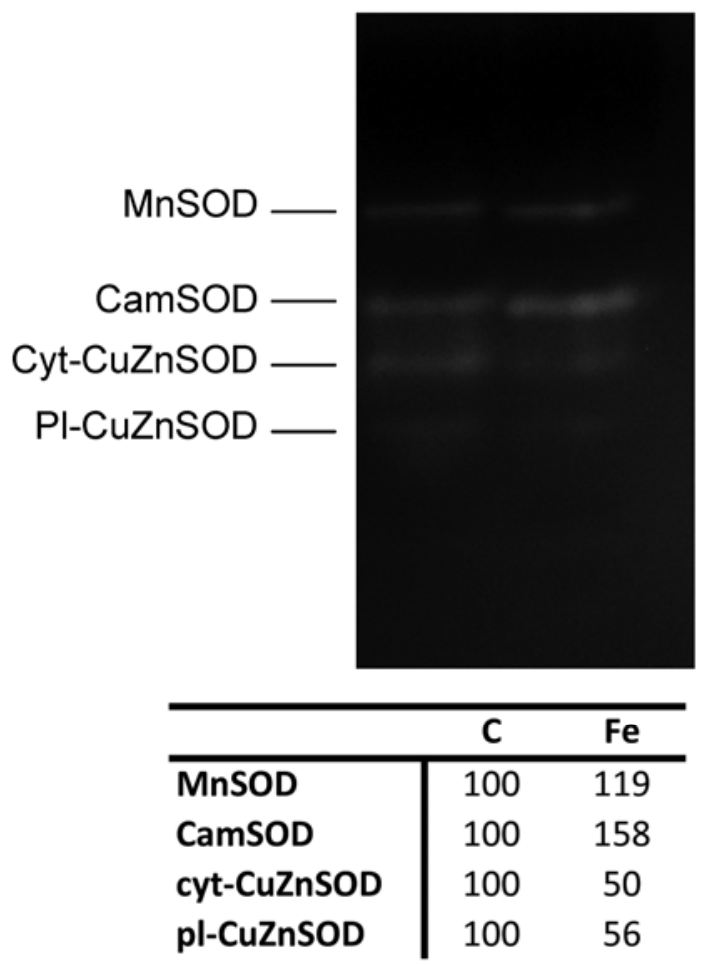

Fig. 4. The effect of $24 \mathrm{~h}$ of Fe(III) EDTA on the superoxide dismutase activities in nodule extracts from 5-week-old pea plants. All lanes were loaded with $60 \mu \mathrm{g}$ of protein. Densitometries of the bands from the Fe treatment are expressed as percentages relative to the corresponding control bands (lower panel). free-living bacteria, bacteroids, and also the plant soluble fraction (Fig. 8A). Interestingly, a band at approximately $50 \mathrm{kDa}$ was observed in the crude extract and in the plant fraction samples, and this was more intense in the MV-treated samples. The immunoblot using the anti-nifDK antibody showed that, although nitrogenase enzyme was present in bacteroids and crude extracts, the plant cell fraction was free of broken bacteroids, both in control and MV-treated nodules (Fig. 8B).

Immunogold labeling was used to ascertain the exact location of CamSOD within pea nodules (Fig. 9). In infected cells of untreated control nodules, in addition to bacteroids (Fig. 9A) and bacteria within infection threads (Fig. 9B), which were labeled as expected, CamSOD localization was also observed within the host cytosol (Fig. 9A to C) and their nuclei (including chromatin) (Fig. 9C). Mitochondria were labeled in both infected and uninfected cells, as were plastids (Fig. 9D). Interestingly, CamSOD was localized within all symplastic subcellular compartments or organelles (except for the vacuole) in all cell types throughout the nodule. CamSOD could also be localized on bacteroids within MV-treated nodules, but localization was less evident in the plant cytosol and organelles (Fig. $9 \mathrm{E})$, probably at least partly because the plant fraction was so degraded by the treatment (Fig. 1F). Sections of control nodules treated with the preimmune serum showed no significant gold labeling (Fig. 9F). Also, labeling with anti-nifH antibody was used as control of the intactness of the bacteroids during the immunogold assay. Immunolocalization of nifH protein was restricted to bacteroids for all treatments.

\section{SodA gene upstream and downstream sequences analysis.}

Based on the R. leguminosarum chromosome sequence, putative promoters were studied within the surroundings of the SodA gene. The search for putative promoter boxes provided a number of potential sequences upstream of the sod gene, including those for canonical -10 and -35 boxes, oxygen- and ROS-response proteins, regulators of the Arg metabolism, and

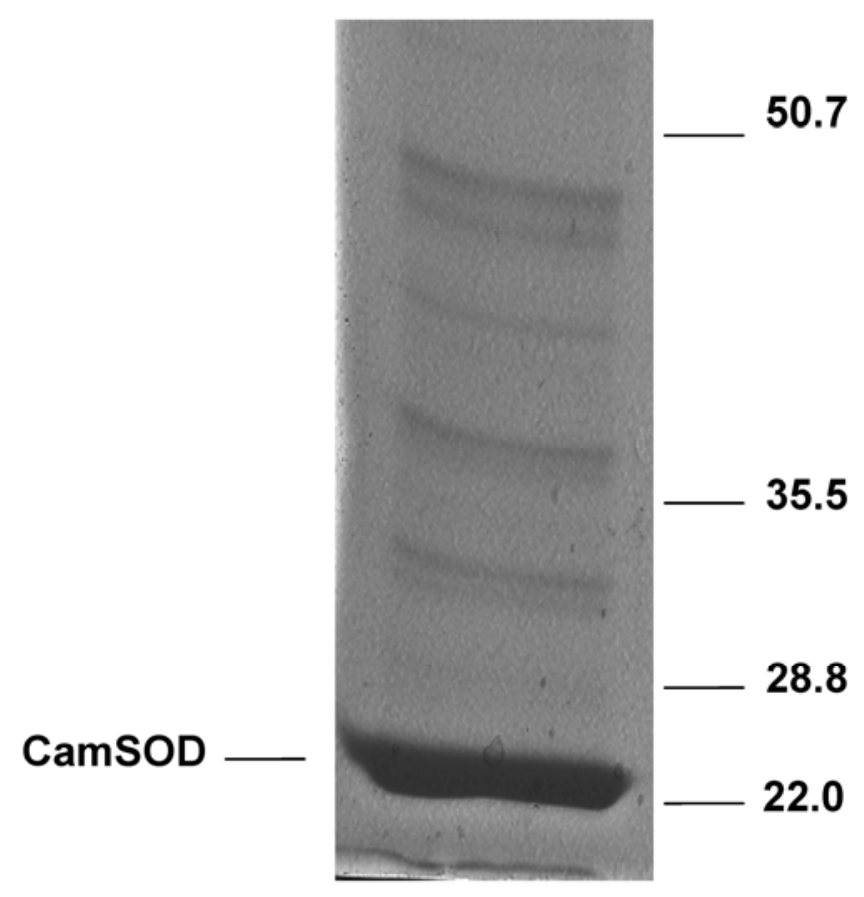

Fig. 5. Sodium dodecyl sulfate-polyacrylamide gel electrophoresis and Coomassie blue-stained gel showing partial purification of the cambialistic superoxide dismutase (CamSOD). A similar fraction was run in parallel and the camSOD band was transferred to polyvinylidene diflouride and was used for $\mathrm{N}$-terminal protein sequencing. Molecular weight markers are indicated. 
control of quorum-sensing genes (Supplementary Fig. S3). One of these is the OxyR transcription factor-regulated promoter, which is regulated by hydrogen peroxide produced via the activity of SOD. The OxyR-regulated promoter is known to trigger the cellular anti-oxidative response, including the induction of SOD (Gonzalez-Flecha and Demple 2000).

A search for coding sequences flanking the sodA gene in the $R$. leguminosarum genome revealed that genes coding for proteins functioning in drug resistance and detoxification, as well as redox-acting proteins exist in proximity to the $\operatorname{sodA}$ gene (Supplementary Fig. S4).

\section{DISCUSSION}

\section{Methylviologen application caused an oxidative stress in pea nodules.}

The application of $10 \mu \mathrm{M} \mathrm{MV}$ in the nutrient solution of nodulated pea plants provoked severe adverse effects on shoot and nodule physiology related to ROS production. The Lb reduction after MV treatment (Table 1) was particularly striking, as total nodule soluble proteins were much less affected by MV than Lb. Lb has been previously shown to be extremely sensitive to redox changes in vitro and in vivo (Marino et al. 2009), and

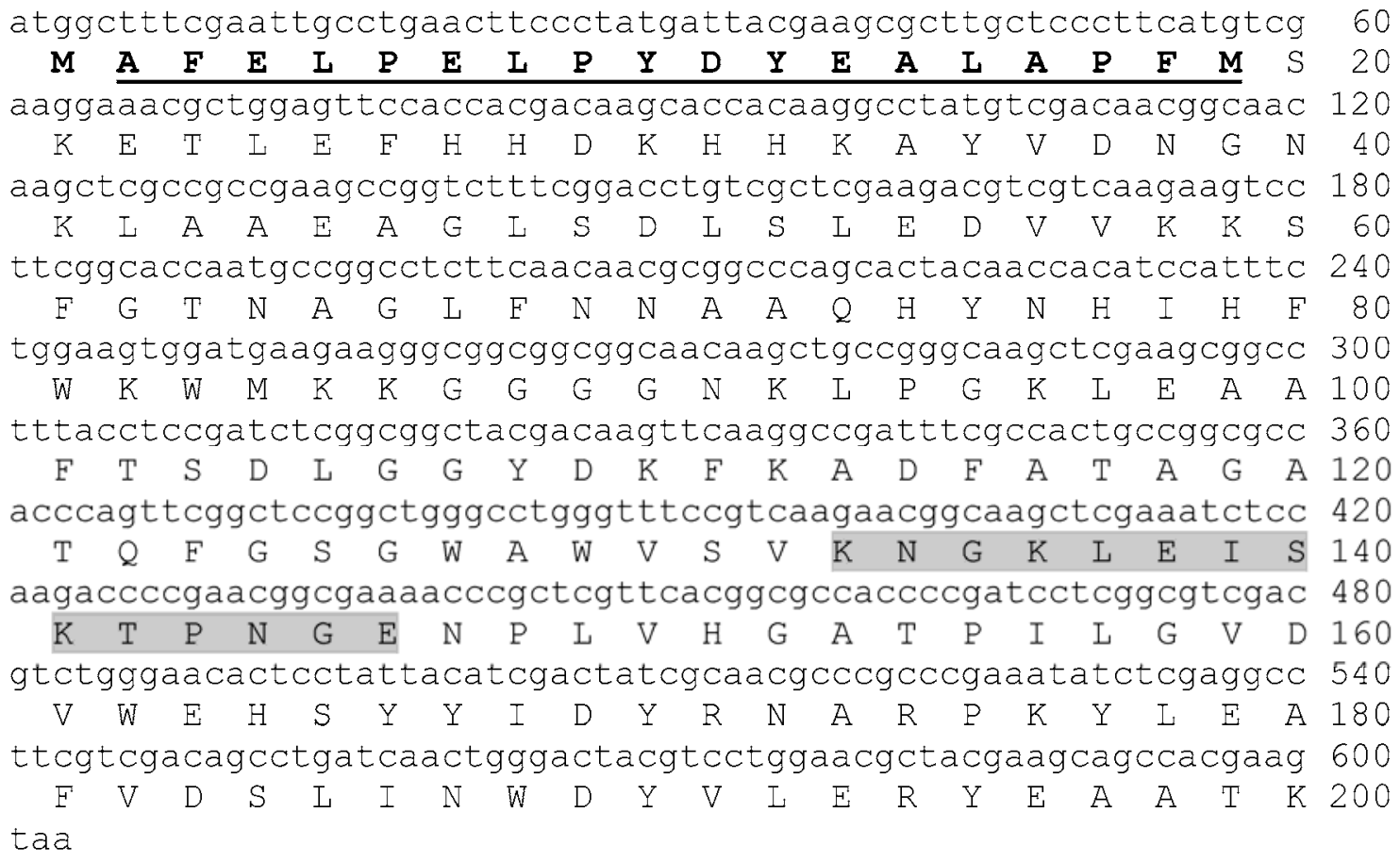

Fig. 6. The full-length nucleotide sequence of the sodA gene from Rhizobium leguminosarum and the predicted protein sequence (cambialistic superoxide dismutase [CamSOD]). N-terminal residues sequenced by Edman degradation are underlined. The shadowed regions indicate the peptide used for immunization of a rabbit for production of an anti-CamSOD antibody.
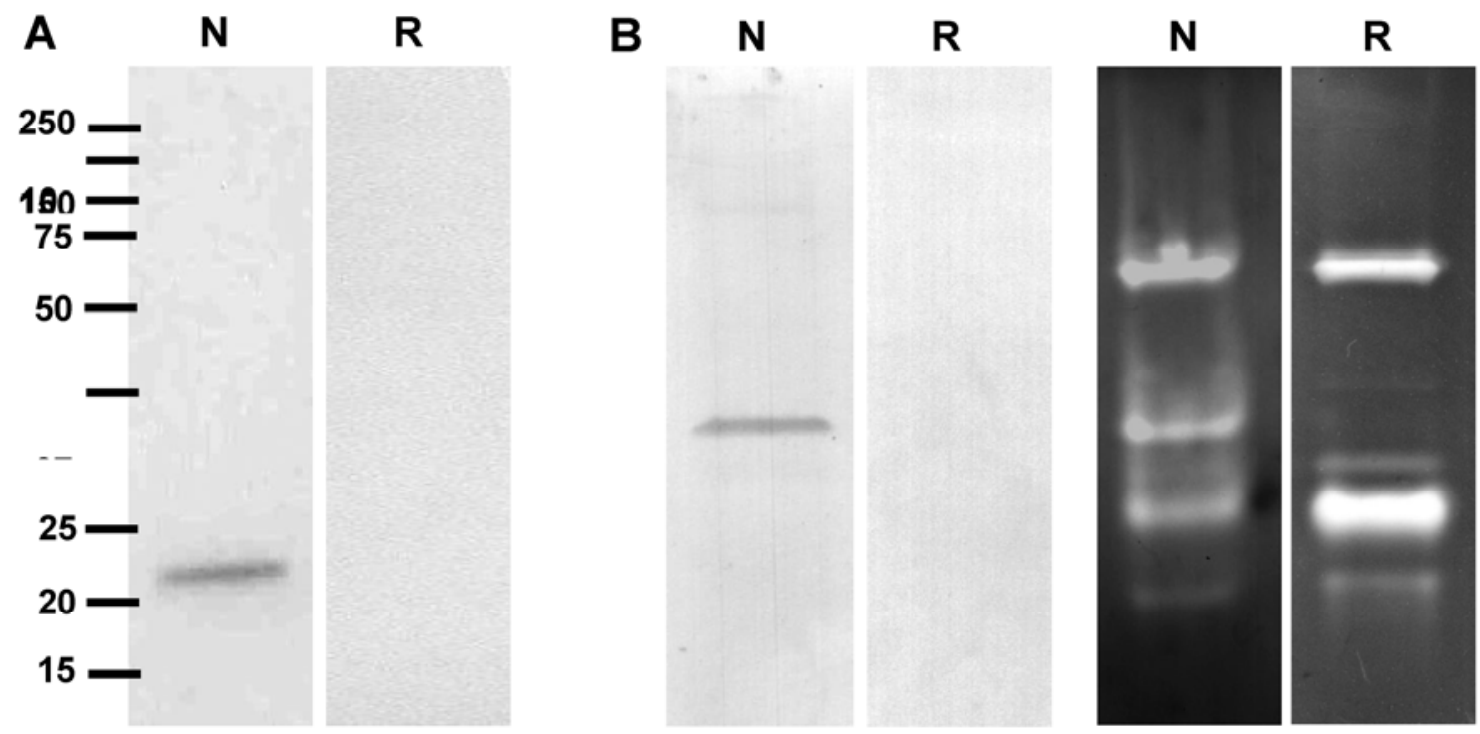

Fig. 7. Cambialistic superoxide dismutase (CamSOD) antibody specificity test using as samples pea nodule (N) and nonnodulated plant roots (R). A, Western-blot with anti-CamSOD after sodium dodecyl sulfate-polyacrylamide gel electrophoresis. B, Native gel electrophoresis; two lanes were transferred to a polyvinylidene diflouride membrane and used for an immunoblot (left) whilst the other two equivalent lanes were stained for in-gel SOD activity (right). 
indeed, the degradation of $\mathrm{Lb}$ has been indicated as a useful marker of nodule oxidative stress (Dalton 1995; Marino et al. 2006). Moreover, the onset of the oxidative stress in pea plants has been related, in part, to the release of Fe from the heme group of $\mathrm{Lb}$, since $\mathrm{Fe}$ contributes to the conversion of $\mathrm{H}_{2} \mathrm{O}_{2}$ and superoxide radicals into extremely reactive hydroxyl radicals (Gogorcena et al. 1995). Also, $\mathrm{Lb}$ is the main reservoir of $\mathrm{O}_{2}$ in the nodule cytosol, and its auto-oxidation generates the superoxide radical (Puppo et al. 1981). Indeed, a strong effect of a superoxide-generating molecule, such as MV, would be expected on nodule performance, as it uses oxygen molecules to transfer electrons, and hence, generates superoxide radicals (Bus et al. 1976). Therefore, the observed decline in BNF under oxidative stress, which was almost a complete suppression of the process, may be attributed more to a reduction in Lb content than to a direct effect on nitrogenase activity. This is also supported by the ultrastructural observations that showed that MV application resulted in severe degradation of the host cytosol but left many of the bacteroids intact (albeit in distorted forms).

In general, the data in the present study indicate that MV has a stronger effect on nodules than on the aerial part of the plant. This is expected because MV is affecting primarily those organs that are directly in contact with the hydroponic solution that contains it (i.e., the roots and nodules), and this most likely explains why the proportional decrease in $\mathrm{N}_{2}$ fixation was greater than that of photosynthesis.

\section{MV application induced the expression of a novel CamSOD in pea nodules.}

We show that MV caused alterations in the pattern of SOD isozyme activities of nodule extracts and, to a lesser extent, within the leaf extracts (Fig. 2). The physiological, anatomical, and protein- or Lb-content data suggest that the nodule cytosol is a cell compartment strongly affected by ROS overproduction. The CamSOD, which exhibits a similar mobility to FeSOD, proved to be one of the main responsive SOD in pea nodules, although it was absent in leaves or roots (Figs. 2 and 7). A pea nodule SOD has previously been shown to be an important responsive enzyme to MV application (Marino et al. 2008), and this was considered to possibly be a FeSOD, based on its mobility in native gels. However, the present study has categorically identified this SOD as a CamSOD, by isolating the active enzyme followed by SDS-PAGE and subsequent Nterminal sequencing. Interestingly, a loss of the initial methionine residue of the CamSOD protein at the $\mathrm{N}$-terminus was observed (Fig. 6). The cytosolic FeSOD from cowpea also loses six amino acids from the N-terminus (Moran et al. 2003), and a similar initial loss of methionine was reported in FeSOD from Anabaena spp. (Li et al. 2002); the authors of the latter study suggested that this loss of amino acids was most likely due to posttranslational removal.

High antibody specificity is crucial for the legitimacy of the immunogold labeling studies. The immunoblot experiments showed that the polyclonal antibody we raised in rabbits against a CamSOD epitope showed no cross-reaction with other related SOD, such as plastidial FeSOD or MnSOD of either bacterial or plant origin, even using the antibody at $1: 1,000$ dilution, the same as was used in the immunolocalization experiments (Fig. 7). Also, it is remarkable that the antinif DK antibody, which was used as a control to confirm that bacteroids remained intact during the mild SOD extraction (Fig. 8B), only detected nitrogenase in crude nodule and bacteroidal extracts but not in the plant-fraction extracts. This fractionation of the pea nodule extract was our first indication that the CamSOD was present in the plant fraction and that its presence was not due to the lysis of bacteroids. Interestingly, a $50-\mathrm{kDa}$ band was apparent in MV-treated plant and nodule fractions (Fig. 8A). This band, which may well correspond to an aggregation form resistant to the SDS-PAGE conditions, arose from oxidation of CamSOD due to the action of MV. An auto-oxidative mechanism has been proposed for the human cytosolic CuZnSOD1 resulting in an aggregation of the enzyme (Hart 2006), and studies using cell culture models have demonstrated that detergents or denaturing agents are unable to dissociate these aggregates (Perry et al. 2010).

\section{Secretion of the CamSOD enzyme}

from bacteroids and its function in the plant fraction.

The CamSOD appears not to be secreted by a classical secretory pathway, as it lacks a putative transit peptide, as indicated by the SignalP software and SecretomeP (Bendtsen et al. 2005). Several types of secretory pathways for proteins have been studied in $R$. leguminosarum and many bacterial proteins have been found to be secreted without any apparent signal peptide, and yet, they have been shown to actively participate in biological processes in the extracellular environment (Krehenbrink and Downie 2008). These include several bacterial SOD, such as Mycobacterium tuberculosis SodA (Bendtsen et al 2005). Given
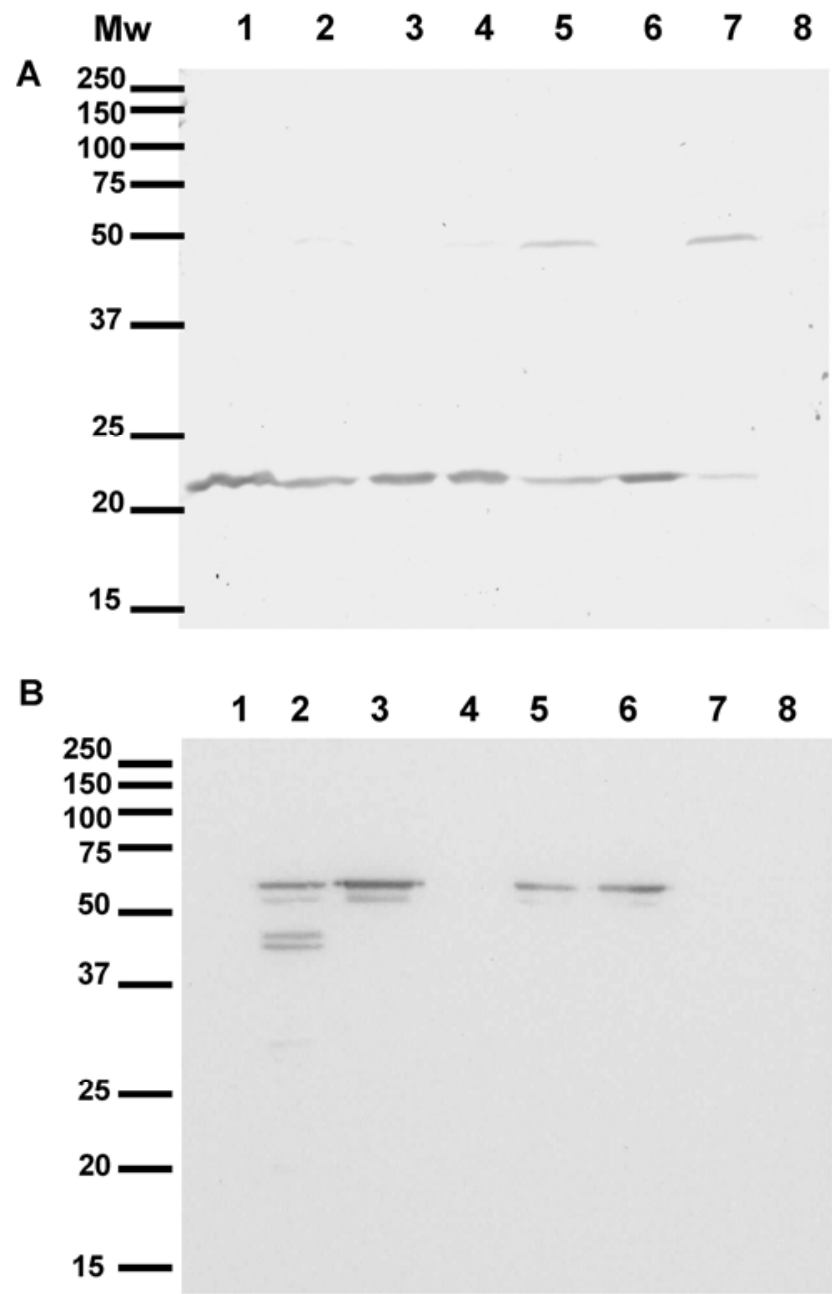

Fig. 8. Sodium dodecyl sulfate-polyacrylamide gel electrophoresis immunoblots of pea nodule extracts (control and methylviologen [MV]-treated) with antibodies against either $\mathbf{A}$, cambialistic superoxide dismutase (CamSOD) or B, nitrogenase. Lane 1, Free-living Rhizobium leguminosarum crude extract; lane 2, pea nodule crude extract; lane 3, pea nodule bacteroidal fraction; lane 4, pea nodule plant fraction; lane 5, MV-treated pea nodule crude extract; lane 6, MV-treated pea nodule bacteroidal fraction; lane 7, MV-treated pea nodule plant fraction; and lane 8, pea leaves crude extract. 
that we have observed a bacterial protein (i.e., CamSOD) within several subcellular locations in both infected and uninfected cells in pea nodules and that nonclassical secretion systems are present in bacteria as well as in eukaryotic cells in plants and are involved in the secretion of several proteins, including SOD (Agrawal et al 2010), it is reasonable to postulate that this system is also used in legume nodules for the transport of bacterial CamSOD (and possibly other SOD [Rubio et al. 2009]) from the cytoplasm to organelles and adjacent cells.

With regard to the extracellular secretion of SOD, the nonpathogenic mycobacterium Mycobacterium smegmatis does not secrete SodA, but interestingly, in the pathogenic $M$. tuberculosis, SodA is secreted in a SecA2 protein-dependent manner. Indeed, SecA2 deletion abolishes SodA secretion in mice, suggesting that nonclassical secretion systems are required for SodA export (Bendtsen et al 2005). Furthermore, in Xanthomonas campestris pv. campestris, one of the most abundant proteins of the extracellular proteome is SodM, a CamSOD homolog that also lacks a secretion signal (Watt et al. 2005). This protein has been described as an inducible elicitor of an oxidative burst in tobacco cell suspension cultures. Smit and associates (1994) showed the induction of SodM in Xanthomonas spp. 3 to $4 \mathrm{~h}$ after its inoculation onto turnip and pepper plants, and they suggested that it may be a defensive reaction of the bacteria to the hypersensitive-response from the plant. The extracellular location of the FeMnCamSOD family of enzymes has been reported for several other bacteria, such as Streptomyces spp. (Folcher et al. 2001; Langlois et al. 2003), cyanobacteria (Ehling-Schulz et al. 2002), and Streptococcus spp. (McMillan et al. 2004). Taken together, these data suggest that CamSOD excretion in pea nodules may be part of the plant-bacterial crosstalk aimed at deactivating the hypersensitive response by the pea plant, and this role might also be extended to other FeSOD in legumes.

Santos and associates $(1999,2000)$ have demonstrated, using $S$. meliloti mutants, that the absence of the CamSOD triggers
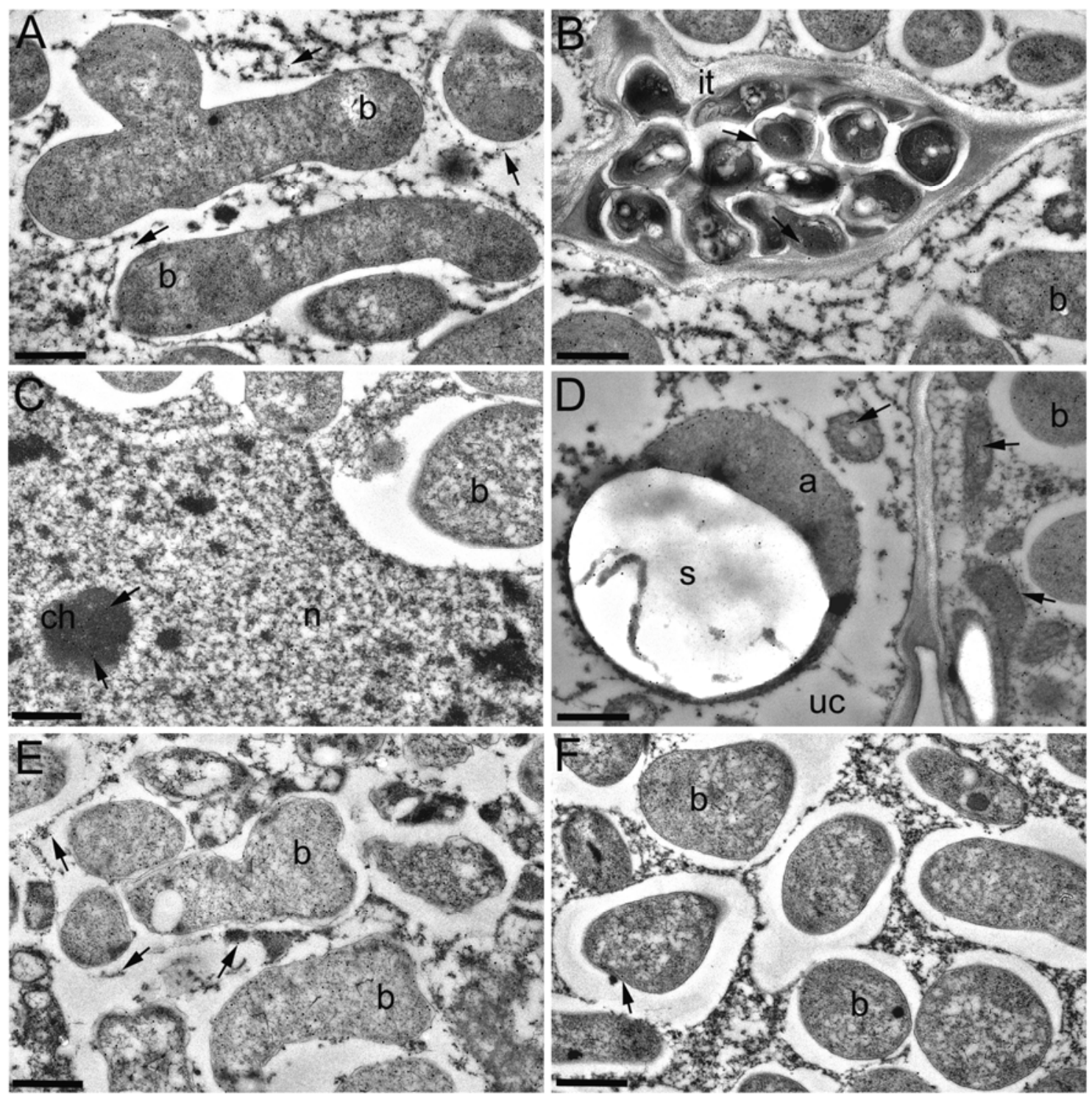

Fig. 9. Immunolocalization of cambialistic superoxide dismutase (CamSOD) in pea nodules. A through $\mathbf{D}$ and $\mathbf{F}$, Sections of control nodules and $\mathbf{E}$, a section of a nodule treated with $10 \mu \mathrm{M}$ methylviologen (MV). A, Localization of CamSOD on bacteroids (b) and in host cell cytoplasm (arrows). B, Localization of CamSOD (arrows) on bacteria within an infection thread (it). C. Localization of CamSOD in the nucleus (n) of an infected cell; note that the chromatin (ch) is also labeled (arrows). D, Localization of CamSOD on an amyloplast (a) within an uninfected cortical cell (uc) and on mitochondria (arrows) within both infected and uninfected cells. $\mathrm{s}=$ starch grain. E, Localization of CamSOD on bacteroids within a MV-treated nodule. Note that the bacteroids (b) are distorted in shape and that there only remnants of immunogold-labeled cytoplasm (arrows). F, Negative control for immunolocalization with preimmune serum substituted for the CamSOD antibody. Very few gold particles (arrow) are present in any cell compartments, such as bacteroids $(b)$. Bars $=1 \mu \mathrm{m}$. 
early senescence both in the nodules as well as in the whole alfalfa plant and, thus, confirmed its requirement for nodule effectiveness. In our study, we show that CamSOD is induced by oxidative stress concomitantly with the degradation of substantial amounts of Lb. Paradoxically, despite its high sensitivity to ROS, Lb is considered to be a very important source of superoxide radicals in the nodule cytosol (Dalton 1995), and it has been shown that ROS production is attenuated when Lb is absent, e.g., in Lotus japonicus Lb-deficient mutants (Günther et al. 2007). Furthermore, Lb degradation is exacerbated under stress conditions and during senescence (Gogorcena et al. 1995) (Table 1), both of which may well increase the concentrations of free Fe in the pea nodule cytosol and, hence, lead to a substantial increase in free radical production (Gogorcena et al. 1995). Thus, it is likely that SOD will provide antioxidant protection in the nodule cytosol under such conditions. In cowpea, the cytosolic FeSOD is related to fully operational nodules, since its expression increases in mature nodules, but it also increases during nodule senescence. As its expression is correlated with Lb synthesis and degradation, it was suggested that cowpea cytosolic FeSOD is regulated in some way by free Fe or heme availability (Moran et al. 2003). In addition, other antioxidant enzymes, such as catalase and ascorbate peroxidase, are up-regulated in plants exposed to excess $\mathrm{Fe}$, and $\mathrm{Fe}$ induced oxidative stress has been proposed as a trigger for ferritin upregulation (Lobréaux et al. 1995). In the present study, we have observed that the CamSOD activity in pea nodules markedly increases when they are grown under conditions of excess Fe (Fig. 4). It has been shown that $\mathrm{Fe}^{2+}$ enters the bacteroid through a divalent metal transporter located in the peribacteroidal membrane that is synthesized by the plant (Kaiser et al. 2003), and therefore, CamSOD synthesis in the bacteroid may be regulated by both the plant and bacterial symbionts via the nodule Fe content.

CamSOD and their related proteins, cowpea nodule FeSOD and the FeSOD of Sesbania rostrata root and stem nodules, have all been localized within the cytosol (Moran et al. 2003; Rubio et al. 2009; this study). Taken together, these results indicate the widespread occurrence of FeMnCamSOD in the cytosol of legume nodules, and the fact that they are mostly absent from the cytosol of nonlegumes suggests that they possibly represent a specialized antioxidant mechanism related to the symbiotic $\mathrm{N}$ fixation process in nodules.

Pea plants have previously been shown to have active FeSOD within plastids (Ariz et al. 2010; Iturbe-Ormaetxe et al. 1998; Rubio et al. 2009; this work), but a more novel location of FeSOD was recently shown for Sesbania rostrata root and stem nodules in which it was localized in the nuclei, particularly on the chromatin (Rubio et al. 2009). We have seen similar results in the present study of pea nodules for the CamSOD, thus suggesting a possible role for FeSOD and CamSOD in the protection of chromatin from ROS. However, as ROS are signaling molecules and all signaling systems need a terminator signal, we cannot discard the possibility that SOD in nuclei are performing this role as part of the signaling system. As the superoxide radical is a charged molecule with a very short life and, hence, has restricted mobility through membranes, the question remains as to what would be the mechanism or the conditions under which superoxide radicals are being either transported into or produced within the nuclei, or both.

In conclusion, in this work, we have purified and identified a CamSOD from Rhizobium leguminosarum and, furthermore, have shown that it is one of the most responsive SOD isozymes against MV-generated oxidative stress in pea nodules. Biochemical assays and immunolocalization studies have demonstrated that CamSOD is present not only in bacteroids but also within the cytosol of both the infected $\mathrm{N}_{2}$-fixing cells and the uninfected cortical and interstitial cells. These findings have thus suggested export of the CamSOD from the bacteria to the plant cells via nonclassical secretion systems. Finally, these results indicate that FeMnCamSOD isozymes may have specific functions in both indeterminate and determinate nodules, including signaling between the plant and the bacterial symbionts and elimination of superoxide in the nucleus.

\section{MATERIALS AND METHODS}

\section{Plant material and treatments.}

Pea seeds (Pisum sativum L. cv. Sugar snap) were grown as described by Marino and associates (2008). Single plants were inoculated with Rhizobium leguminosarum bv. viciae NLV8 1 week after sowing, when seedlings had reached a height of 2 to $3 \mathrm{~cm}$. Plants were grown in pots in a $1: 1$ ( $\mathrm{vol} / \mathrm{vol})$ perlite/vermiculite mixture at $22^{\circ} \mathrm{C}$-day and $18^{\circ} \mathrm{C}$-night temperature, $70 \%$ relative humidity, $500 \mu \mathrm{mol}$ photons $\mathrm{m}^{-2} \mathrm{~s}^{-1}, 15-\mathrm{h}$ photoperiod and were watered with a $\mathrm{N}$-free nutrient solution. Four-week-old plants were transferred to 1-liter hydroponic tanks 4 days prior to treatment imposition.

For the MV treatments, plants were divided randomly into two sets, which were exposed to 0 (controls) or $10 \mu \mathrm{M} \mathrm{MV}$ hydrate (Sigma-Aldrich, St. Louis) for $96 \mathrm{~h}$. For the microscopy experiments, a treatment with $1 \mu \mathrm{M}$ MV for 4 days was also applied. Plant dry weights were determined after drying for $48 \mathrm{~h}$ at $80^{\circ} \mathrm{C}$. Fresh nodule aliquots were immediately frozen in liquid nitrogen and were stored at $-80^{\circ} \mathrm{C}$ for analytical determinations. For the Fe-excess treatment, 4-week-old plants were divided randomly into two sets, which were exposed for $24 \mathrm{~h}$ either to $100 \mu \mathrm{M} \mathrm{Fe}$ (III)-EDTA or to $100 \mu \mathrm{M} \mathrm{Na} \mathrm{N}_{2}$-EDTA (control). To determine the effects of increased nodule age on the response of nodules to $\mathrm{MV}$, plants were grown for 10 weeks.

\section{SOD activity staining.}

The SOD isozyme pattern was analyzed by activity staining following electrophoresis on $15 \%$ nondenaturing polyacrylamide gels. Nodules or roots were ground with an extraction buffer consisting of $50 \mathrm{mM}$ potassium phosphate ( $\mathrm{pH} 7.8$ ), 0.1 $\mathrm{mM}$ EDTA, $0.1 \%$ (vol/vol) Triton X-100, and $1 \%$ (wt/vol) polyvinylpyrrolidone-10. The extract was filtered through cheesecloth and was centrifuged at $12,000 \times g$ at $4^{\circ} \mathrm{C}$ for 20 min to remove cell debris. Samples were electrophoresed and gels were stained, based on the inhibition of the reduction of nitro blue tetrazolium (NBT) by superoxide radicals generated photochemically (Beauchamp and Fridovich 1971). The identification of the different isozymes was based on the differential inhibition of SOD activity on gels preincubated with either $3 \mathrm{mM} \mathrm{KCN}$ or $5 \mathrm{mM} \mathrm{H}_{2} \mathrm{O}_{2}$ for $1 \mathrm{~h}$.

\section{Physiological and biochemical parameters.}

The contents of ASC, DHA, GSH, and GSSG in nodule extracts were analyzed by high-performance capillary electrophoresis as described by Zabalza and associates (2008). Protein and $\mathrm{Lb}$ determinations were performed as described by Marino and associates (2006).

\section{SOD purification and $\mathrm{N}$-terminal sequencing.}

A total of $17 \mathrm{~g}$ of nodules were homogenized using a pestle and mortar with the addition of $50 \mathrm{ml}$ of $100 \mathrm{mM}$ potassium phosphate buffer $(\mathrm{pH} 7.8)$ containing $0.1 \mathrm{mM}$ EDTA and $5 \mathrm{~g}$ polyvinylpolypyrrolidone. The resulting sample was filtered through a Miracloth sheet and centrifuged for $20 \mathrm{~min}$ at $18,000 \times g$. The supernatant was dialyzed against column buffer (10 mM potassium phosphate buffer, $\mathrm{pH} 7.8)$ and was 
loaded into a 5-ml Hitrap-DEAE Sepharose fast flow column (GE Healthcare, Piscataway, NJ, U.S.A.), and a 100-ml gradient of potassium phosphate buffer $(\mathrm{pH} 7.8)$ ranging from 10 to $100 \mathrm{mM}$ was used to release the protein from the column. Fractions were assayed using the SOD activity assay, and those containing CamSOD were pooled, dialyzed, and applied to a HiTrap-Mono Q Sepharose Fast flow column (GE Healthcare) column equilibrated with the column buffer described above. Protein was eluted using a gradient of 0 to $500 \mathrm{mM}$ $\mathrm{NaCl}$ in $10 \mathrm{mM}$ potassium phosphate buffer ( $\mathrm{pH} 7.8$ ). Fractions were assayed in gel for SOD activity, and active CamSOD bands from native gels were excised, were eluted from the gels, and were concentrated and loaded onto SDS gels as described by Moran and associates (2003). The SDS gels were transferred to PVDF membranes, and $\mathrm{N}$-terminal sequencing was performed on selected bands by Edman degradation.

\section{Fractionation of nodule extracts.}

Fresh nodules were homogenized with a pestle and mortar in potassium phosphate buffer $(50 \mathrm{mM}, \mathrm{pH} 7.4)$ plus mannitol $(0.2 \mathrm{M})$ and were then filtered. This crude extract was immediately centrifuged for $5 \mathrm{~min}$ at $400 \times \mathrm{g}$. The pellet, largely consisting of cell debris, was discarded, and the supernatant was centrifuged again for $10 \mathrm{~min}$ at $2,500 \times g$. After this step, the supernatant mainly consisted of cytosolic and particulate cell components, while the pellet was mainly bacteroids (Trinchant et al. 2004).

Antibody production and protein inmunoblotting assays.

For CamSOD antibody production the peptide KNGKLEIS KTPNGE was selected on the basis of its antigenic properties and its exposed position in the protein structure. This peptide was chemically synthesized (Thermo Scientific, Beverly, MA, U.S.A.) and was used for rabbit immunization and immunoglobulin $\mathrm{G}$ ( $\mathrm{IgG}$ ) purification (Biogenes, Berlin).

Protein extracts $(5 \mu \mathrm{g}$ of protein per lane for anti-nifDK and $30 \mu \mathrm{g}$ for anti-CamSOD) were loaded onto $12 \%$ (wt/vol) SDSPAGE and were electroblotted onto $0.45 \mu \mathrm{M}$ polyvinylidene difluoride membranes (Pall Corporation, Pensacola, FL, U.S.A.). Either anti-CamSOD or antinitrogenase (anti-nifDK; Allen et al. 1993) primary antibodies were used at 1:10,000 dilution, except for the assay shown in Figure 7, in which a dilution of 1:1,000 of anti-CamSOD was employed. The secondary antibodies employed in the assays were goat anti-rabbit IgG alkaline phosphatase conjugate (1:10,000, vol/vol; SigmaAldrich) or horseradish peroxidase conjugate (1:20,000, vol/vol; Sigma-Aldrich). Immunoreactive bands were visualized with the NBT and 5-bromo-4-chloro-3-indolyl-phosphate system (Sigma-Aldrich) or with a chemiluminescent substrate (SuperSignal West Pico, Pierce, Rockford, IL, U.S.A.), respectively.

\section{Microscopy and immunogold labeling.}

Fresh samples of control and MV-treated pea nodules were fixed and embedded for light microscopy and TEM according to Madsen and associates (2010). Briefly, nodules were fixed in $2.5 \%$ glutaraldehyde in $0.1 \mathrm{M}$ sodium cacodylate $(\mathrm{pH} 7.0)$ overnight at $4{ }^{\circ} \mathrm{C}$ and were subsequently dehydrated in an ethanol series and were embedded in LR White acrylic resin (Agar Scientific, Standsted, U.K.). Semithin sections $(1 \mu \mathrm{m})$ were taken for light microscopy and ultrathin $(80 \mathrm{~nm})$ sections were taken for TEM, using a Leica UCT ultramicrotome. The semithin sections were collected on glass slides and were stained with $0.1 \%$ toluidine blue, whereas the ultrathin sections were collected on pioloform-coated nickel grids and were immunogold labeled with an antibody against the nifH protein of Rhodospirillum rubrum (diluted 1:100) or with the CamSOD antibody (diluted 1:1,000) according to the protocols of
Rubio and associates (2009). The ultrathin sections were stained with uranyl acetate for $10 \mathrm{~min}$, before being viewed and digitally photographed using a JEM 1400 transmission electron microscope (JEOL, Tokyo). For negative controls, serial sections were immunogold labeled with preimmune serum (diluted 1:1,000).

\section{In silico analysis.}

Swiss-Model software of the Swiss Institute of Bioinformatics (Lausanne, Switzerland) was used for generate a 3-D model of the Rhizobium leguminosarum CamSOD protein (UniProtKB and TrEMBL accession number: Q1MJM3-1). The CamSOD sequence was analyzed with the Signal $P$ and SecretomeP 2.0 software (Center for Biological Sequence Analysis, Technical University of Denmark, Lyngby) in order to search for possible classical and nonclassical protein secretion signals (Bendtsen et al. 2004, 2005).

\section{ACKNOWLEDGMENTS}

Authors wish to thank P. Ludden and A. Noren, respectively, for the kind gifts of the anti-nitrogenase nif-DK and nifH antibodies and to E. M. González and E. Larrainzar for help with Table 1 and with the fractionation experiments, respectively. This work was supported by the Spanish MICIIN (grant numbers AGL2007-64432AGR and AGL2010-16167). A. C. Asensio was supported by a doctoral contract within Euroinnova Navarra Programme (Expte. IIM10784.RI1), Government of Navarra, Department of Innovation, Business and Employment. I. Ariz was supported by a doctoral fellowship from the Public University of Navarre.

\section{LITERATURE CITED}

Alscher, R. G., Erturk, N., and Heath L. S. 2002. Role of superoxide dismutase (SODs) in controlling oxidative stress in plants. J. Exp. Bot. 53:1331-1341.

Agrawal. G. K., Jwa, N. S., Lebrun, M. H., Job, D., and Rakwal. R. 2010 Plant secretome: Unlocking secrets of the secreted proteins. Proteomics 10:799-827.

Allen, R. M., Homer, M. J., Chatterjee, R., Ludden, P. W., Roberts, G. P., and Shah, V. K. 1993. Dinitrogenase reductase- and MgATP-dependent maturation of apodinitrogenase from Azotobacter vinelandii. J. Biol. Chem. 268:23670-23674.

Apel, K., and Hirt, H. 2004. Reactive oxygen species: Metabolism, oxidative stress, and signal transduction. Ann. Rev. Plant Biol. 55:373399.

Ariz, I., Esteban, R., García-Plazaola, J. I., Becerril, J. M., Aparicio-Tejo, P. M., and Moran, J. F. 2010. High irradiance induces photoprotective mechanisms and a positive effect on $\mathrm{NH}_{4}{ }^{+}$stress in Pisum sativum L. J. Plant Physiol. 167:1038-45.

Bannister, J. V., Bannister, W. H., and Rotilio, G. 1987. Aspects of the structure, function and applications of superoxide dismutase. CRC Crit. Rev. Biochem. 22:111-180.

Beauchamp, C., and Fridovic, I. 1971. Superoxide dismutase-Improved assays and an assay applicable to acrylamide gels. Anal. Biochem. 44:276-287.

Bendtsen, J. D., Nielsen, H., von Heijne, G., and Brunak, S. 2004. Improved prediction of signal peptides: SignalP 3.0. J. Mol. Biol. 340:783-795.

Bendtsen, J. D., Kiemer, L., Fausboll, A., and Brunak, S. 2005. Non-classical protein secretion in bacteria. BMC Microbiol. 5:58.

Bus, J. S., Aust, S. D., and Gibson, J. E. 1976. Paraquat toxicity-Proposed mechanism of action involving lipid peroxidation. Environ. Health Persp. 16:139-146.

Dalton, D. A. 1995. Antioxidant defenses in plant and fungi. Pages 298355 in: Oxidative Stress and Antioxidant Defenses in Biology. Chapman Hall, New York.

Ehling-Schulz, M., Schulz, S., Wait, R., Gorg, A., and Scherer S. 2002. The UV-B stimulon of the terrestrial cyanobacterium Nostoc commune comprises early shock proteins and late acclimation proteins. Mol. Microbiol. 46:827-843.

Folcher, M., Gaillard, H, Nguyen, L. T., Nguyen, K. T., Lacroix, P. Bamas-Jacques, N., Rinkel, M., and Thompson, C. J. 2001. Pleiotropic functions of a Streptomyces pristinaespiralis autoregulator receptor in development, antibiotic biosynthesis, and expression of a superoxide dismutase. J. Biol. Chem. 276:44297-44306.

Gogorcena, Y., Iturbe-Ormaetxe, I., Escuredo, P. R., and Becana, M. 1995. 
Antioxidant defenses against activated oxygen in pea nodules subjected to water-stress. Plant Physiol. 108:753-759.

Gonzalez-Flecha, B., and Demple, B. 2000. Genetic responses to free radicals. homeostasis and gene control. Ann. NY Acad. Sci. 899:69-87.

Gunther, C., Schlereth, A., Udvardi, M., and Ott, T. 2007. Metabolism of reactive oxygen species is attenuated in leghemoglobin-deficient nodules of Lotus japonicus. Mol. Plant-Microbe Interact. 20: 1596-1603.

Hart, P. J. 2006. Pathogenic superoxide dismutase structure, folding, aggregation and turnover. Curr. Opin. Chem. Biol. 10:131-138.

Iturbe-Ormaetxe, I. Escuredo, P. R., Arrese-Igor, C., and Becana, M., 1998. Oxidative damage in pea plants exposed to water deficit or paraquat. Plant Physiol. 116: 173-181

Kaiser, B. N., Moreau, S., Castelli, J., Thomson, R., Lambert, A., Bogliolo, S., Puppo, A., and Day, D. A. 2003. The soybean NRAMP homologue, GmDMT1, is a symbiotic divalent metal transporter capable of ferrous iron transport. Plant J. 35:295-304.

Krehenbrink M., and Downie, J. A., 2008. Identification of protein secretion systems and novel secreted proteins in Rhizobium leguminosarum bv. viciae. BMC Genomics 9:55-61.

Ken, C. F., Hsiung, T. M., Huang, Z. X., Juang, R. H., and Lin, C. T. 2005. Characterization of Fe/Mn superoxide dismutase from diatom Thallassiosira weissflogii: Cloning, expression, and property. J. Agric. Food Chem. 53:1470-1474.

Langlois, P., Bourassa, S., Poirier, G. G., and Beaulieu, C. 2003. Identification of Streptomyces coelicolor proteins that are differentially expressed in the presence of plant material. App. Environ. Microbiol. 69:1884-1889.

Li, T., Huang, X., Zhou, R..B., Liu, Y..F., Li, B., Nomura, C., and Zhao, J..D. 2002. Differential expression and localization of Mn and Fe superoxide dismutases in the heterocystous cyanobacterium Anabaena sp. strain PCC 7120. J. Bacteriol. 184:5096-5103.

Lobreaux, S., Thoiron, S., and Briat, J. F. 1995. Induction of ferritin synthesis in maize leaves by an iron-mediated oxidative stress. Plant $\mathrm{J}$. 8:443-449.

McMillan D. J., Davies, M. R., Good, M. F., Sriprakash, K. S. 2004. Immune response to superoxide dismutase in group A streptococcal infection. FEMS Immunol. Med. Mic. 40:249-256.

Madsen, L., Tirichine, L., Jurkiewicz, A., Sullivan, J., Heckmann, A., Bek, A., Ronson, C., James, E. K., and Stougaard, J. 2010. The molecular network governing nodule organogenesis and infection in the model legume Lotus japonicus. Nat. Commun. 1. doi:10.1038/ncomms1009. Published online.

Marino, D., Gonzalez, E. M., and Arrese-Igor, C. 2006. Drought effects on carbon and nitrogen metabolism of pea nodules can be mimicked by paraquat: Evidence for the occurrence of two regulation pathways under oxidative stresses. J. Exp. Bot. 57:665-673.

Marino, D., Hohnjec, N., Kuster, H., Moran, J. F., Gonzalez, E. M., and Arrese-Igor, C. 2008. Evidence for transcriptional and post-translational regulation of sucrose synthase in pea nodules by the cellular redox state. Mol. Plant-Microbe Interact. 21:622-630.
Marino, D., Pucciariello, C., Puppo, P., and Frendo, P. 2009 The redox state, a referee of the legume-rhizobia symbiotic game. Adv. Bot. Res. 52:115-151.

Moran, J. F., James, E. K., Rubio, M. C., Sarath, G., Klucas, R. V., and Becana, M. 2003. Functional characterization and expression of a cytosolic iron-superoxide dismutase from cowpea root nodules. Plant Physiol. 133:773-782

Perry, J. J. P., Shin, D. S., Getzoff, E. D., and Tainer, J. A. 2010. The structural biochemistry of the superoxide dismutases. BBA-Proteins Proteom. 1804:245-262.

Puppo, A., Rigaud, J., and Job, D. 1981. Role of superoxide anion in leghemoglobin autoxidation. Plant Sci. Lett. 22:353-360.

Rubio, M. C., James, E. K., Clemente, M. R., Bucciarelli, B., Fedorova, M., Vance, C. P., and Becana, M. 2004. Localization of superoxide dismutases and hydrogen peroxide in legume root nodules. Mol. Plant-Microbe Interact. 17: 1294-1305.

Rubio, M. C., Becana, M., Kanematsu, S., Ushimaru, T., and James, E. K. 2009. Immunolocalization of antioxidant enzymes in high-pressure frozen root and stem nodules of Sesbania rostrata. New Phytol. 183:395-407.

Santos, R., Bocquet, S., Puppo, A., and Touati, D. 1999. Characterization of an atypical superoxide dismutase from Sinorhizobium meliloti. J. Bacteriol. 181:4509-4516.

Santos, R., Herouart, D., Puppo, A., and Touati, D. 2000. Critical protective role of bacterial superoxide dismutase in Rhizobium-legume symbiosis. Mol. Microbiol. 38:750-759.

Smit W. J., Boquest A. L., Geddes J. E., and Tosolini F. A. 1994. The antibiotic susceptibilities of Xanthomonas maltophilia and their relation to clinical management. Pathology 26:321-324.

Torres, M. A. 2010. ROS in biotic interactions. Physiol. Plantarum 138:414429.

Trinchant, J. C., Boscari, A., Spennato, G., Van de Sype, G., and Le Rudulier, D. 2004. Proline betaine accumulation and metabolism in alfalfa plants under sodium chloride stress. Exploring its compartmentalization in nodules. Plant Physiol. 135:1583-1594.

Watt, S. A., Wilke, A., Patschkowski, T., and Niehaus, K. 2005. Comprehensive analysis of the extracellular proteins from Xanthomonas campestris pv. campestris B100. Proteomics 5:153-167.

Young, J. P., Crossman, L. C., Johnston, A. W., Thomson, N. R., Ghazoui, Z. F., Hull, K. H., Wexler, M., Curson, A. R., Todd, J. D., Poole, P. S., Mauchline, T. H., East, A. K., Quail, M. A., Churcher, C., Arrowsmith, C., Cherevach, I., Chillingworth, T., Clarke, K., Cronin, A., Davis, P., Fraser, A., Hance, Z., Hauser, H., Jagels, K., Moule, S., Mungall, K., Norbertczak, H., Rabbinowitsch, E., Sanders, M., Simmonds, M. Whitehead, S., and Parkhill, J. 2006. The genome of Rhizobium leguminosarum has recognizable core and accessory components. Genome Biol. 7: R34.

Zabalza, A., Gálvez, L., Marino, D., Royuela, M., Arrese-Igor, C., and González E. M., 2008. The application of ascorbate or its immediate precursor, galactono-1,4-lactone, does not affect the response of nitrogen-fixing pea nodules to water stress. J. Plant Physiol. 165:805-812. 